\title{
跳水から発生する低周波音の予測 LOW FREQUENCY SOUND BY HYDRAULIC JUMP
}

\author{
桜井 力 $^{1} \cdot$ 京藤 敏達 $^{2} \cdot$ 西村 仁嗣 2 \\ Tsutomu SAKURAI, Harumichi KYOTOH and Hitoshi NISHIMURA \\ 1正会員 工修 水資源開発公団 企画部調査課（テ107-8488 東京都港区赤坂5-3-3） \\ 2 正会員 工博 筑波大学 機能工学系（テ305-8573 茨城県つくば市天王台1-1-1）
}

\begin{abstract}
Hydraulic jump of high-Froude number flow entrains air bubbles with high concentrations, thus scattering lowfrequency sound to the environment. In the present study, the frequency of the sound scattered from a dissipater of a spillway was predicted by the Helmholtz equation derived from a phenomenological equation of multi-phase flow. This low frequency sound was considered to be generated by the oscillation of the bubble cloud in the region of dissipater with high void ratio.

Based on the Helmholtz equation for sound wave, the eigen-value problem was solved analytically for the simplified models of the dissipater and numerically for the more practical model. The eigen-frequencies obtained from these models were compared to the experimental results and shown to be well-predicted by the present method.
\end{abstract}

Key Words : Hydraulic jump, low frequency sound, air bubbles, dissipater, the Helmholtz equation, eigen-value problem

\section{1. 序論}

ダムに設けられる洪水吐きは、洪水時の流水を安全か つ確実に下流に流下させるための施設であるが、ダムを 流下する水は大きなエネルギーを持っており、下流保護 のために必要がある場合にはエネルギーを減じるための 減勢工が設けられる。減勢工には様々な型式があるが、 現在、我が国で最も採用事例が多いのは、副ダムによっ て下流水深を確保し、水平な水吅き上に強制的に跳水を 発生させる「副ダムを有する跳水式减勢工」と呼ばれる 型式である. 跳水は、流水が射流加常流に変化する急 変現象であるが、その際に生じる大きな乱れによって、 そのエネルギーの一部が、熱や音に変換されることによ り、減勢効果が発揮される.

減勢は水脈の持つエネルギーの一部が熱や音に変 換することによって達成されるため音の発生は避け られない。これらダム放流水の減勢時に発生する音 は、人間には聞こえにくい $20 \mathrm{~Hz}$ 以下の周波数成分 が卓越した周波数特性を持つことが現地観測結果等 から知られている ${ }^{112.2}$ 。この低周波音が大きい場合 や長期に亘る場合などに周辺の建物の空ガラスや建 物内の建具を振動させる等の問題を引き起こしてお
り、早急な現象の解明と低減対策の確立が求められ ている.

しかし、現時点では、ダム計画段階で、放流時の 低周波音の発生がある程度予想されても、定量的な 予測が困難であることや抜本的な対策が確立してい ないことから、設計において発生音対策が講じられ ることはほとんどない. そのため、運用を開始して から発生音が問題となり、対策を迫られる事例が見 受けられる。しかし、ダムが完成し、運用を開始し てしまうと、発生音源側での対策は一層難しくなり、 結局、対策は家屋の補強等の対症療法的なものにな らざるを得ない。したがって、ダムの計画・設計段 階において発生音を定量的に予測し、具体的な対策 を講じておくことが望ましく、そのための検討手法 を確立する必要がある。

減勢池内の流れは気液混相流であり、このような

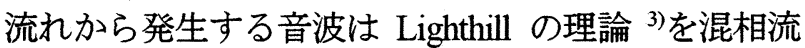
の方程式に適用することによって検討されている ${ }^{4)}$. すなわち、跳水内部からの発生音には、渦による音、 気泡混入時の気泡生成音、混入された気泡群から放 射される音などが挙げられる。これらの発生音で最 も減衰が小さく、かつ、低周波の振動は気泡群から 放射される音である ${ }^{5)}$ （したがって、本論文では減勢池 


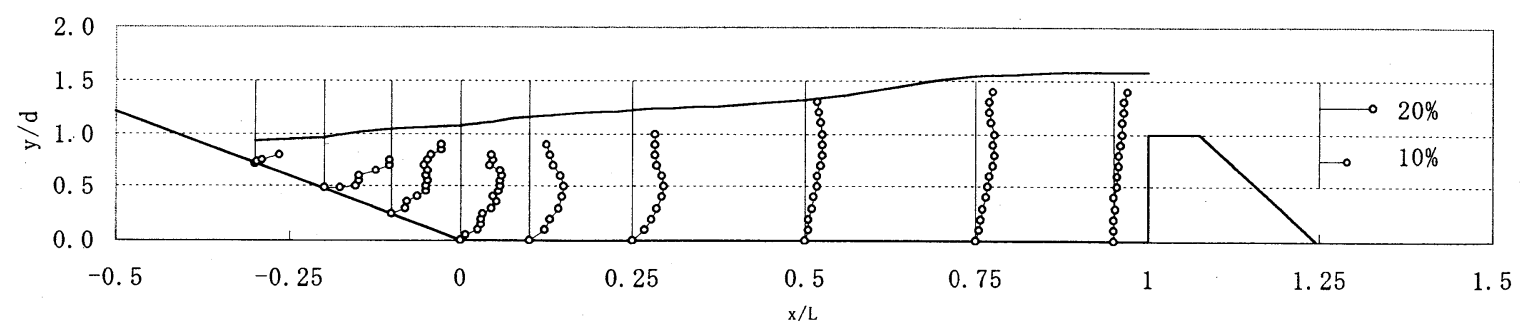

図-1 減勢池内のボイド率分布および水面形(実験No. 2-1:2倍モデル, フルード数 $=8.4, \mathrm{~L}=2.61 \mathrm{~m}, \mathrm{~d}=0.435 \mathrm{~m}$ )

から発生する低周波音の原因が跳水時に減勢工内に連 行される気泡群の振動によるものと考え、その放射さ れる音の予測を行った.

\section{2. 気泡群の振動によって発生する音}

（1）減勢池から放射される音のスペクトル

以下では、桜井・柏井・小野(6)による跳水式减勢工か らの登牛音に関する実験データに基づいて議論を行う。 実験は、幾何学的に相似で大きさの異なる 4 種類の模型 を用いて行った. 各模型の大きさは、最も小さい模型を 基準として、それぞれ 2 倍、3倍および 4 倍となってい る. ただし、現象の 2 次元性を仮定し、水路幅は全模型 とも $20 \mathrm{~cm}$ とている. 図-1には 2 倍モデルの流れの様子 が示されており、跳水始端部から斜面端部にかけてボイ ド率の大きな領域が存在し、下流側ではボイド率は徐々 に減少している．なお、ポンプ運転音等の暗騒音を別途 測定し、測定音から差し引いている。

図-2は跳水始端部直上で計測した音のパワースペクト ルの周波数 $200 \mathrm{~Hz}$ までの值を各モデルにおいてプロット したものである．実験における発生音も、100Hz以下に 複数のピークを持つ人間の耳には聞き取りにくい低周波 数帯が卓越した音となっている。跳水時に混入される気 泡の径は $1 \sim 2 \mathrm{~cm}$ であり、その固有振動数は数百ヘルツ となる.したがって、図-2に現れる複数のピークは、単 一気泡の固有振動によるものではない.

\section{（2）気泡群の振動によって発生する音の基礎式}

気泡群が放射する音は、大気から海洋に砕波によって 取り込まれる空気量を推定する際の一方法として研究さ れている ${ }^{7)}$ ，すなわち、海洋表層の気泡群が放射する音 の振動数を計測することによって、この気液混相流体の ボイド率を推定することができる. 気泡を含んだ混相流 体中の音速は、混相流体の質量保存則および運動量保存 則から容易に導かれ、流速に比べて音速が非常に大きい 場合には、

$$
\begin{aligned}
& c_{m}=\left(\rho_{m} K_{m}\right)^{-1 / 2}, \\
& \rho_{m}=\rho_{a} \beta+\rho_{w}(1-\beta), \\
& K_{m}=\frac{\beta}{\rho_{a} c_{a}{ }^{2}}+\frac{1}{\rho_{w} c_{w}{ }^{2}}(1-\beta)
\end{aligned}
$$
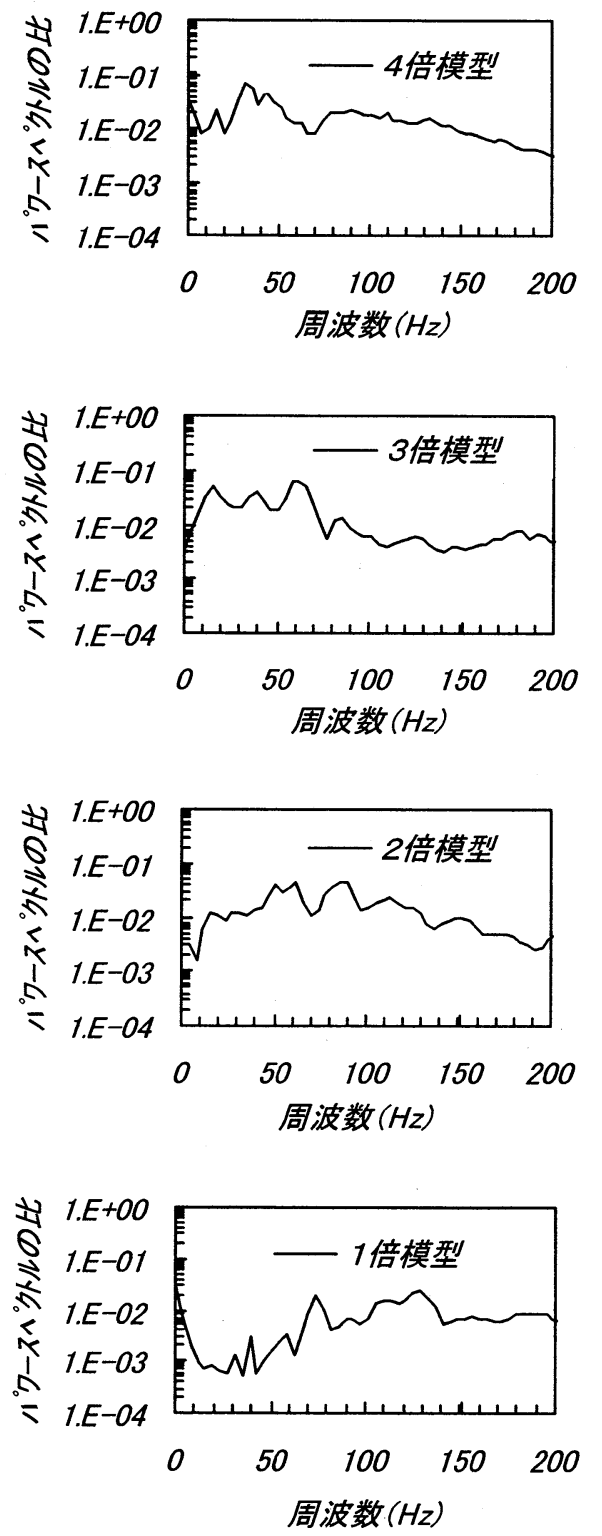

図-2 発生音のパワースペクトル

(1，2，3，4倍模型における副ダムの高さdはそれぞれ $\mathrm{d}=21.8,43.5,65.3,87 \mathrm{~cm}$ 、副ダムまでの距離Lは、 $\mathrm{L}=130.5,260.9,391.4,521.8$ cmである. ) 


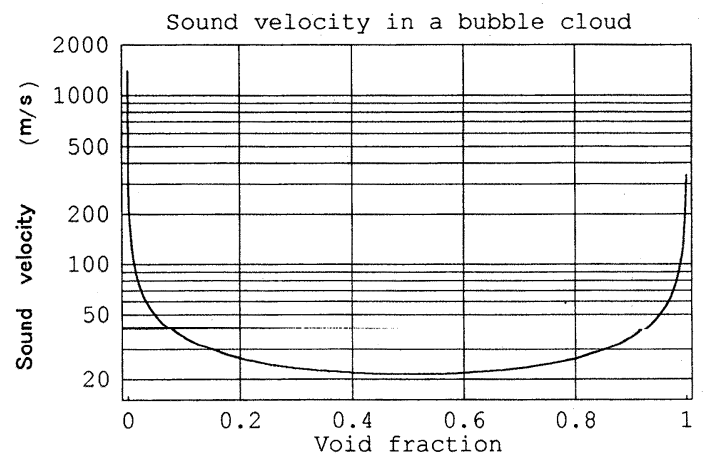

図-3 ボイド率と音速の関係

となる ${ }^{8)}$.ここで混相流体の密度を $\rho_{m}$ 、音速を $c_{m}$ 、体積 弾性率を $K_{m} 、 \beta$ をボイド率、空気および水の密度を $\rho_{a}, \rho_{w}$ 、それら媒質中の音速を $c_{a}, c_{w}$ とした. 図-3に式 （1）㘦算定した水-空気混相流中の音速を示す．ここで は、空気および水の物性值として以下の值を用いた。

$$
\begin{aligned}
& \rho_{a}=1 \mathrm{~kg} / \mathrm{m}^{3} ; \quad \rho_{w}=1000 \mathrm{~kg} / \mathrm{m}^{3} \\
& c_{a}=340 \mathrm{~m} / \mathrm{s} ; \quad c_{w}=1400 \mathrm{~m} / \mathrm{s}
\end{aligned}
$$

この図から、水中に僅かな気泡が分散することによって 音速が急激に減少することがわかる．ただし、式(1)は 水および空気の粘性および熱伝導性を無視したときの表 式であり、気泡が固有振動数近辺で振動している場合に は適用されないフ。

本研究で対象とする現象は高レイノルズ数の気液混相 状態にあり、その流れは複雑な乱流である.この乱流中 の気泡の変形をモデル化することは困難なため、ここで はこれを無視する．また、粘性や熱伝導の効果は乱流に よる擾乱に比べて小さいため、これらも無視する.ささら に、この気液混相流が発する音は極度に複雑であるが、 ここで注目する音は乱流変動より遥かに低周波で波長は 水深スケール、しかもその水中音速は流速より数オーダ 大きいため、流れとの相互作用を無視する. 上記の議論 から、跳水中の圧力変動を次のへルムホルツ方程式

$$
\frac{\partial^{2} p_{m}}{\partial x^{2}}+\frac{\partial^{2} p_{m}}{\partial y^{2}}+\kappa_{m}{ }^{2} p_{m}=0, \quad \kappa_{m}=\frac{2 \pi f}{c_{m}}
$$

により記述する ${ }^{9}$.ここで、 $x, y$ は減勢池の流れ方向お よび鉛直方向座標、 $p_{m}$ は圧力の複素振幅, $\kappa_{m}$ は波数,

$f$ は振動数， $c_{m}$ は混相流中の音速である. 以下では式 （3）に基づいて減勢池内での音波および空中への音の放 射について検討する.

\section{（3）音波の境界条件}

音波に対する境界条件は、境界が透過壁，反射壁もし くは媒質間の界面の場合で異なる。透過壁では $p=0$ ， 反射壁では $\partial p / \partial n=0$ ( $n$ は壁面法線方向座標), 媒質 1 , 2 の界面の場合には、(1)媒質 1 と 2 が同じ物質で構成さ れるときは圧力および質量流速の連続条件 $\left(\rho_{1} u_{1}=\rho_{2} u_{2}\right)$ :

$$
p_{1}=p_{2} ; \frac{\partial p_{1}}{\partial n}=\frac{\partial p_{2}}{\partial n} \quad \text { at } n=0
$$

(2)媒質間で物質のやり取りがない場合には界面の圧力お よび法線方向流速が等しくなる条件

$$
p_{1}=p_{2} ; \frac{1}{\rho_{1}} \frac{\partial p_{1}}{\partial n}=\frac{1}{\rho_{2}} \frac{\partial p_{2}}{\partial n} \quad \text { at } n=0
$$

が適用される.ここで、 $u_{1}, u_{2}$ は界面における法線方向 流速、下付き添字 1,2 は媒質 1 および 2 における物理量 を意味する. また、上式(4)，(5)の第2式は線形化した才 イラーの運動方程式を使って流速の条件を圧力条件で表 現したものである.

以下で、気液混相流が空気に接するときの境界条件を $\rho_{a} \ll<\rho_{m}$ のもとで簡略化する. ただし、音波の加速度 が重力加速度に比べて非常に大きく、重力の効果は無視 できるとする.また、この界面変位は非常に小さいとす る. 物理量の大きさを見積もるために、無次元化

$$
N=n / h ; p_{m}=\rho_{m} c_{m}{ }^{2} P_{m} ; p_{a}=\rho_{a} c_{a}{ }^{2} P_{a}
$$

を行う。このとき境界条件は、

$$
\begin{aligned}
& \rho_{m} c_{m}{ }^{2} P_{m}=\rho_{a} c_{a}{ }^{2} P_{a} \\
& c_{m}{ }^{2} \frac{\partial P_{m}}{\partial N}=c_{a}{ }^{2} \frac{\partial P_{a}}{\partial N}, \quad N=0
\end{aligned}
$$

で与えられる．ただし、 $N=0$ は界面の位置を表す．先 の仮定に基づいて摂動展開

$$
\begin{aligned}
& P_{a}=P_{a 0}+\gamma P_{a 1}+\gamma^{2} P_{a 2}+\ldots \\
& P_{m}=P_{m 0}+\gamma P_{m 1}+\gamma^{2} P_{m 2}+\ldots \\
& \rho_{a} / \rho_{m} \equiv \gamma
\end{aligned}
$$

を境界条件 (7)に代入し摂動パラメータ $\gamma$ の幕でまとめ、 各幕の倸数を 0 と置くと、初項から

$$
\begin{aligned}
& P_{m 0}=0 \\
& \frac{\partial P_{a 0}}{\partial N}=\chi^{2} \frac{\partial P_{m 0}}{\partial N}, \quad \chi \equiv \frac{c_{m}}{c_{a}}, \quad N=0
\end{aligned}
$$

が得られる.また高次項は

$$
\begin{aligned}
& P_{m j}=\frac{1}{\chi^{2}} P_{a j-1} . \\
& \frac{\partial P_{a j}}{\partial N}=\chi^{2} \frac{\partial P_{m j}}{\partial N}
\end{aligned}
$$

である. 一方、 $P_{m j}, P_{a j}, j=0,1,2, \ldots$, に対する基礎方程式 は式(3) と同型となる. 本研究で対象とする音波の場合 には、摂動展開 (8) が収束するための十分条件 $O\left(\gamma / \chi^{2}\right)=1 \& O\left(\chi^{2}\right)=1$ を満たすことに注意する.し たがって、まず境界条件 (9) の第 1 式から空気の影響が ないときの気液混相流体中の圧力振幅 $P_{m 0}$ を求め、次に その混相流体が界面に励起寸る圧力勾配を式(9)の第2式 から与え、最終的に空気中の圧力振幅 $P_{a 0}$ を算定するこ とができる. 


\section{3. 減勢池における音波の固有振動}

減勢池から空中に放射される音波は、2(3)節で議論 したように、減勢池内で励起され増幅された音波が自由 表面の流速変動を通して空中に伝播するものと解釈する ことができる. したがって、本章ではこの減勢池におけ る音波の固有モードを調べることによって、先に示した 実験結果の説明を試みる。この際、図-1に示した減勢池 の形状およびボイド率の分布が固有モードに与える効果

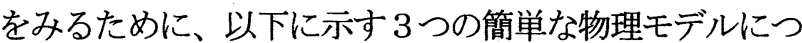
いて解析を行った．図-4では流入口付近のボイド率を $\beta_{1} 、$ そ以外の部分のボイド率を $\beta_{2}$ とした.

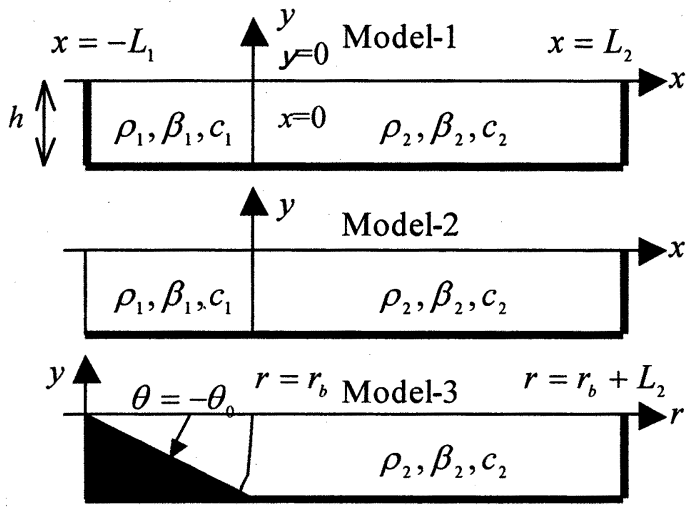

図-4 減勢池のモデル

図中太線は完全反射の境界を意味する. また、 $x=0$ を 境にボイド率が $\beta_{1}$ から $\beta_{2}$ に変化する.

(Model-1： $x=-L_{1}$ の直立壁は完全反射、Mode1-2: $x=-L_{1}$ は自由表面、Mode1 $-3: x<0$ に斜面)

\section{（1）矩形領域の固有振動数}

斜面の効果を相対的にみるために、まず図-4のMode11, Mode1-2の直立境界を持つ减勢池の固有振動について 検討し、Mode1-3と比較する. 以下、簡単のため、ボイ ド率 $\beta_{1}$ の領域を領域 $1, \beta_{2}$ の領域を領域 2 と呼ぶ.

矩形領域の場合にはヘルムホルツ方程式(3) は変数分 離法で容易に解くことができる. Mode1-1の解は、

$$
\begin{aligned}
& p_{1}=A_{1} \sin (\lambda y) \cos \left(\mu_{1}\left(x+L_{1}\right)\right) \\
& p_{2}=A_{2} \sin (\lambda y) \cos \left(\mu_{2}\left(x-L_{2}\right)\right) \\
& \mu_{1}=\sqrt{\kappa_{1}^{2}-\lambda^{2}} ; \mu_{2}=\sqrt{\kappa_{2}^{2}-\lambda^{2}} \\
& \kappa_{1}=2 \pi f / c_{1} ; \kappa_{2}=2 \pi f / c_{2}
\end{aligned}
$$

ここで、下付き添字の1,2はそれぞれ領域 $1 ， 2$ におけ る値を示す. さらに、上式中の固有値 $\lambda, \mu_{1}, \mu_{2}$ は底面お よび領域 1,2 の解の接合条件 (4) から次式を満たすこと が示される。

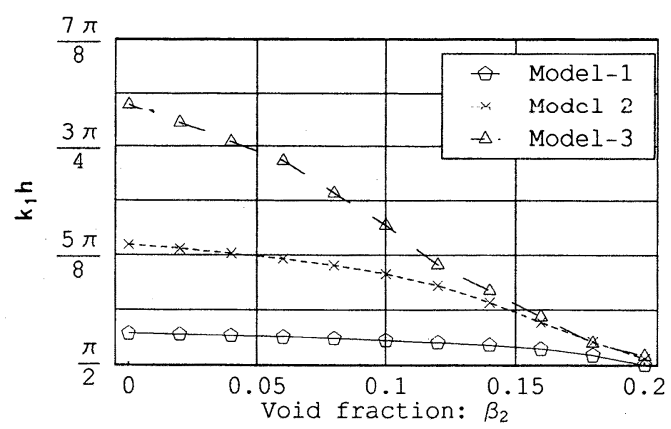

図-5＼cjkstart基本モードの波数と下流側ボイド率の関係

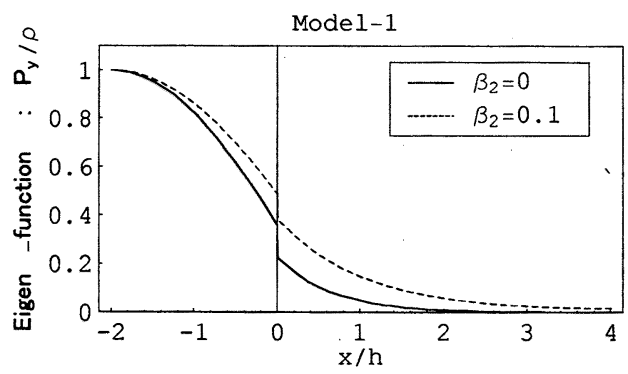

(a) $x=-L_{1}$ は完全反射境界 $\left(\beta_{1}=0.2\right)$

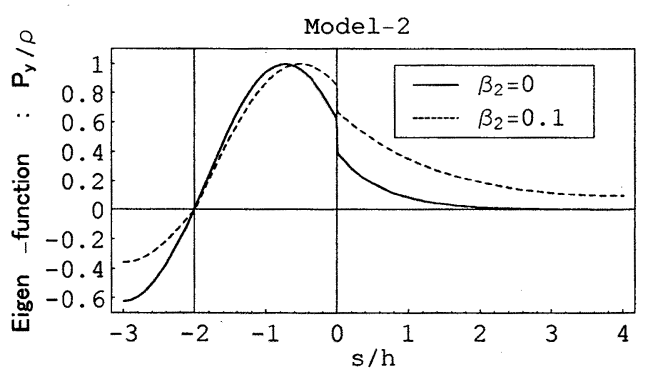

(b) $x=-L_{1}$ は透過境界 $\left(\beta_{1}=0.2\right)$

図-6 基本モードの透過境界における勾配

$\rho_{1}^{-1} \partial p_{1} / \partial n$ および $\rho_{2}^{-1} \partial p_{2} / \partial n$ ただし、図の縦軸は最大值が 1 となるように正規化されて いる．また、図(b)の横軸は自由境界に沿ってとった座標で $-3<s / h<-2$ は $x=-L_{1}$ の自由表面に対応する.

$$
\begin{aligned}
& \lambda=\frac{\pi}{2 h}(2 m-1), \quad m=1,2,3, \ldots, \\
& \mu_{1} \tan L_{1} \mu_{1}+\mu_{2} \tan L_{2} \mu_{2}=0
\end{aligned}
$$

同様にMode1-2の解および固有值は

$$
\begin{aligned}
& p_{1}=A_{1} \sin (\lambda y) \sin \left(\mu_{1}\left(x+L_{1}\right)\right) \\
& p_{2}=A_{2} \sin (\lambda y) \cos \left(\mu_{2}\left(x-L_{2}\right)\right) \\
& \mu_{1}=\sqrt{\kappa_{1}^{2}-\lambda^{2}} ; \mu_{2}=\sqrt{\kappa_{2}^{2}-\lambda^{2}} \\
& \kappa_{1}=2 \pi f / c_{1} ; \kappa_{2}=2 \pi f / c_{2}
\end{aligned}
$$




$$
\begin{aligned}
& \lambda=\frac{\pi}{2 h}(2 m-1), \quad m=1,2,3, \ldots, \\
& -\mu_{1} \cot L_{1} \mu_{1}+\mu_{2} \tan L_{2} \mu_{2}=0
\end{aligned}
$$

となる.

具体的に気液混相流の基本モード $(m=1)$ につて検 討する.ここで、減勢池内上流側のボイド率は、図-1か らおよそ $\beta_{1}=0.2$ とし、その領域の長さ $L_{1}$ は斜面部分 の領域に対応させるために $L_{1}=2 h$ とする. さらに、減 勢池下流側のボイド率は０から0.2まで変化させ、そ の領域の長さ $L_{2}$ は $L_{2}=4 h$ に固定する. すると、固有 值方程式(12) もしくは(14) から振動数 $f$ が決定される. 図-5にこれらの方程式から求めた基本モード $(m=1)$ の 無次元波数 $\kappa_{1} h$ をボイド率 $\beta_{2}$ の関数としてプロットし た. $\kappa_{1} h=\pi / 2$ は水深方向に $1 / 4$ 波長のモ一ドが自由振 動モードとなることを意味する.この図から、減勢池の 上流から下流にかけて気泡が減少するにしたがって基本 モードの振動数が増加することがわかる.

次に、減勢池で励起された音波の空中への放射につい て考察する. 2 ( 3)節で考察したように空中への音波の 放射は $\rho_{m}{ }^{-1} \partial p_{m} / \partial n$ の絶対值に比例する.ここでは減勢 池表面上で放射される音の大きさの分布形状をみるため に正規化された $\rho_{m}{ }^{-1} \partial p_{m} / \partial n$ の值をプロットした（図-6 参照）。予想されるようにボイド率の大きい方の領域 1 において空中への音の放射が大きくなる．また、 $\beta_{2}=\beta_{1}=0.2$ の場合にはこの分布形状が大きく変化す ることを考えると、ボイド率の変化がこの音の放射に大 きく関与することが理解される.

\section{（2）楔形領域の固有振動数}

前節ではボイド率の空間分布が音の放射にどのように 影響するかについて調べた。ここでは、図-1のように斜 面上の三角形領域が存在する場合、その効果について検 討する.

前節と同様に図-4のMode1-3 をボイド率の異なる $2 つ$ の領域に分け、それぞれの領域における解を求め、それ らを接合することによって基本モードおよび固有振動数 を求める。まず、領域 1 (ボイド率 $\beta_{1}$ ) は半径 $r_{b}=h / \sin \theta_{0}$, 内角 $\theta_{0}=\pi / 6$ の扇形領域とし、残りを 領域 2 (ボイド率 $\beta_{2}$ ) とする. このとき領域 1,2 におけ る基本解は

$$
\begin{aligned}
& p_{1}=J_{\ell}\left(\kappa_{1} r\right) \sin \ell \theta ; \quad \ell=n_{0}(m-1 / 2) ; n_{0}=\pi / \theta_{0} \\
& p_{2}=\sin (\lambda r \sin \theta) \cos \mu_{2}\left(r \cos \theta-L_{2}-r_{b} \cos \theta_{0}\right) \\
& \lambda=\frac{\pi}{2 h}(2 m-1) ; \quad \mu_{2}=\sqrt{\kappa_{2}{ }^{2}-\lambda^{2}}
\end{aligned}
$$

となる. ただし、 $J_{\ell}$ は第 1 種 $\ell$ 次のベッセル関数である. 次に、接合条件 (4) を満たす解を構成する必要があるが、 矩形領域同士の接合と異なり、この解は式(15)の基本解 の線形和として表される. 基本モードを求める際には、 式(15) の基本解を5 項程度 $(m=1,2, \ldots, 5)$ 用いれば十分

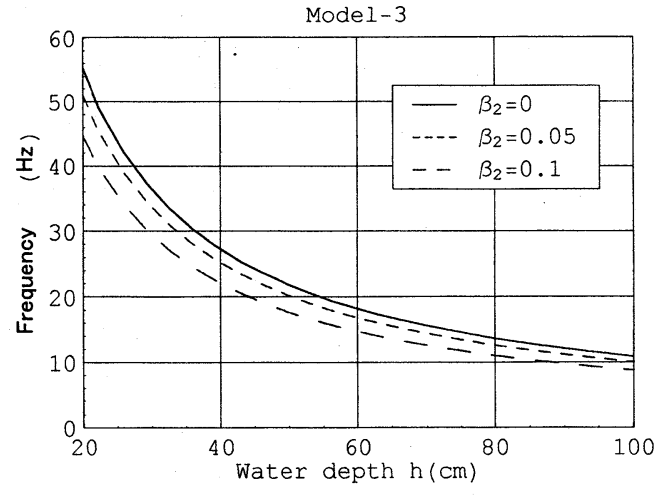

図-7 基本モードの振動数と水深の関係

上図は、図-5からMode1 3の波数を各 $\beta_{2}$ の值に対して読 み取り、 $\kappa_{1} h=2 \pi f h / c_{1}$ より周波数 $f$ を算定したもので ある.

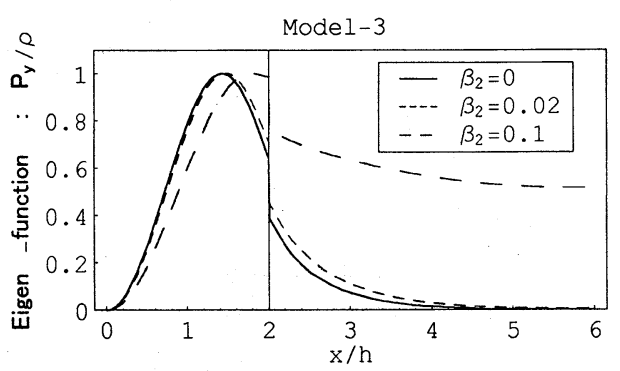

図-8 基本モードの自由境界における勾配 $\rho_{1}^{-1} \partial p_{1} / \partial n$ および $\rho_{2}^{-1} \partial p_{2} / \partial n$ ただし、図の縦軸は最大值が 1 となるように正規化されて いる.

である.これらの線形和で与えた解を式(4)に代入し、 前節と同様に固有值および固有関数を決定することがで きる.

図一济に上記の解析から得られた基本モ一ドの波数を示 す.この図から、ボイド率の大きな三角形領域の存在は 固有振動の振動数を増加させることが分かる. 図-7は、 図-5から読夕取ったModel-3の基本モードの波数を音波 の分散関係式 $c_{m}=2 \pi f / \kappa_{m}$ に代入し、振動数 $f$ と水深 $h$ の関係をプロットしたものである. 水深 $h$ として大ま かに副ダムの高さ $d$ を用いると、振動数の理論值は実験 值(図-2)の最初の卓越振動数に近い值を与える. 実験值 に見られる複数の卓越振動数が理論による高次モード $(m \geq 2)$ に対応するものかどうかは不明である. 仮に実 験で高次モードが支配的となるとすれば、その原因を調 ベる必要がある.

図-8にMode1-3における正規化された $\rho_{m}{ }^{-1} \partial p_{m} / \partial n$ の 值をプロットした（図-6と比較）。予想されるようにボ イド率の大きい方の領域 1 において空中への音の放射が 大きくなり、この傾向は領域 1 と領域 2 のボイド率に差 があるほど顕著に現れる.

以上のことから、減勢池から放射される低周波の音波 は自由表面に接したボイド率の大きな領域が音源となっ て放射されると考えられる. 


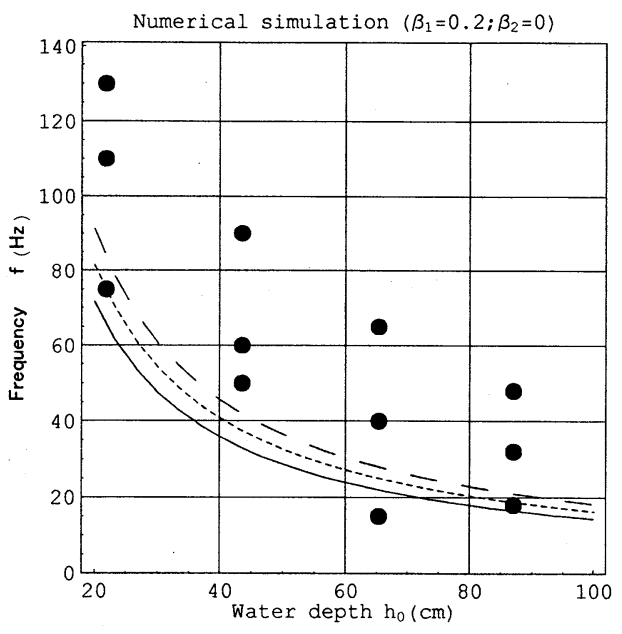

図-9 固有振動の理論值および実験值の比較 図中の実線は基本モード、点線は 2 倍、破線は 3 倍 モードの振動数である.また、黒丸○は図-2のパワー のピークを与える振動数を大きい方から 3 つ選んでブ ロットした.

\section{（3）減勢池の固有振動数}

実験では、ボイド率は流れ方向のみでなく水樑方向に も大きく変化している. ボイド率は基本モードおよびそ の振動数を決定する上で重要な支配パラメータである. そこで、基礎方程式(3)をボイド率の空間変化が緩やか な場合にも適用し、变数係数のへルムホルツ方程式(3) の固有値を数值的に決定することによって、実験值との より正確な比較を試みる.

図-1から、ボイド率の分布を水深方向に放物形、流下 方向に線形の関数で与える. すなわち、

$$
\beta=\beta_{s}\left(1-\frac{y^{2}}{h(\tilde{x})^{2}}\right) ; \quad \beta_{s}=\beta_{1}+\frac{\beta_{2}-\beta_{1}}{L_{1}+L_{2}} \tilde{x}
$$

ここで、 $\widetilde{x}=r_{b}+x 、 h(\tilde{x})$ は水深、 $\beta_{1}, \beta_{2}$ はそれぞれ水 面における流入端および流出端のボイド率である. 式 (16)で与えられるボイド率は、減勢池底面で 0 、水面で 最大をとる。また、簡単のため、斜面勾配は $1 / 2$ 、 $L_{1}+L_{2}=6 h_{0}\left(h_{0}\right.$ は水平床上の水深)、

$$
h(\tilde{x})=\left\{\begin{array}{cc}
\tilde{x} / 2 & \text { for } \quad 0 \leq \tilde{x} \leq 2 h_{0} \\
h_{0} \quad \text { for } \quad 2 h_{0} \leq \tilde{x} \leq L_{1}+L_{2}
\end{array}\right.
$$

とする.

ヘルムホルツ方程式 (3) に二次精度の中心差分を適用 し、境界条件は斜面、底面および副ダム上で完全反射条 件、水面で透過条件を与える. この方程式系が非自明解 を持つ条件、すなわち差分化で得られた線形代数方程式 系の係数行列の行列式が 0 となるように振動数 $f$ を決 定すればよい. 図-9は、 $\beta_{1}=0.2, \beta_{2}=0$ の場合の基本, 2 倍および3倍モードの振動数 $f$ を水深 $h_{0}$ の関数として プロットしたものである. また、図中黒丸は図-2 に示 したパワースペクトルのピークを示す．図-7と比較する
と振動数が高周波側にずれていることがわかる.これは、 式(16)のボイド率が水深方向にも減少するように設定し たためである. 実験值は、これら理論值より大き目であ るが、基本モードと考えられる低周波側の值は理論值に 近い值を与える.

\section{4. まとめ}

減勢池内の気泡群の固有振動数を求め、減勢池から空 中に放射される音の振動数について議論した. その結果、 ボイド率の大きな楔形領域の存在が、実験で測定された 振動数を説明するために重要であることが判明した。 ま た、ヘルムホルツ方程式の固有值問題を数值的に解いて 得られた固有振動数（図-9）は、実験值（図-2）を良好 に近似していると考えられる。

気液混相流中の気泡は一般に乱流の最小渦に比べて大 きいため、乱流によって振動エネルギーを奪われる4). したがって、跳水による気泡の混入および振動の励起が なければ気泡群の運動は減衰する.このことから、気泡 混入時の気泡振動の励起が低周波音の外力として作用し、 これが低周波音の発生メカニズムの解明にとって重要で あることが理解される. 今後、流下に伴うボイド率の変 化および跳水形状予測と併せて、気泡混入過程を探求す ることが課題となる.

謝辞：本研究をまとめるに当たり、筑波大学機能工学 系 青島伸治教授および松内一雄教授には有益な批評を 頂きました.ここに、感謝の意を表します。

\section{参考文献}

1）金沢純一, 金安公造 : ダムの放流に伴う低周波騒音の発生と 伝播, 日本音響学会講演論文集, pp. 179-180, 1976.

2) 近畿地方建設局, 淀川ダム統合管理事務所 : 天ヶ瀬ダム放流 に伴う低周波音実態調査報告書, pp. 1-60, 1978.

3) Lighthill, M.J.: Waves in Fluids, Cambridge Univ. Press, 1978.

4) Crighton, D.G. and J.E. Ffowcs Williams: Sound generation by turbulent two-phase flow, J. Fluid Mech., V. 36, pp. 585-603, 1969.

5) Prosperetti, A.: Bubble-related ambient noise in the ocean, J. Acoust. Soc. Am., 84(3), pp. 1042-1054, 1988.

6) 桜井 力, 柏井条介, 小野雅人：跳水式减勢工の発生音特性と その予測手法, ダム工学, V. 11, No. 2, pp. 117-129, 2001.

7) Oguz, H.N.: A theoretical study of low-frequency oceanic ambient noise, J. Acoust. Soc. Am., 95(4), pp. 1895-1912, 1994.

8) Gibson, F.W.: Measurement of the effect of air bubbles on the speed of sound in water, J. Acoust. Soc. Am., 13(3), pp. 1195-1197, 1970.

9) Commander, K.W. and Prosperetti A.: Linear pressure waves in bubbly liquids: Comparison between theory and experiments, J. Acoust. Soc. Am., 85(2), pp. 732-746, 1989.

(2001. 10.1受付) 